\title{
Incidental uptake of fluorodeoxyglucose in the Waldeyer's ring and risk of oropharyngeal malignancy
}

\author{
Iulia Bujoreanu ${ }^{1,2}$ (D) $\cdot$ Dorothy Gujral ${ }^{1,2} \cdot$ Kathryn Wallitt $^{3} \cdot$ Zaid Awad $^{1,2}$
}

Received: 12 June 2021 / Accepted: 12 September 2021 / Published online: 27 September 2021

(c) Crown 2021

\begin{abstract}
Purpose Fluorodeoxyglucose (FDG) positron emission tomography (PET) is increasingly used to diagnose and stage malignancy. The aim of this article is to investigate the significance of incidental FDG uptake in the Waldeyer's ring and to assess its value in predicting clinically occult oropharyngeal malignancy.

Methods All FDG-PET/CT scans performed in Imperial College NHS Foundation Trust, UK between January 2012 and November 2018 were included. Patients with known or suspected oropharyngeal malignancy or lymphoma were excluded. Minimum follow-up was 12 months.

Results A total of 724 scans revealed oropharyngeal uptake of FDG. Of these, 102 were included in the study. Most patients $(62.1 \%)$ were scanned as part of staging for other malignancies. Oropharyngeal FDG uptake was asymmetrical in $57.3 \%$ of the cases. Uptake was more common in the tonsils (56.3\%), followed by the tongue base (31.1\%) and both sites (12.6\%). In $41.7 \%$ of reports, appearance was described as likely physiological; however, $52.4 \%$ of reports advised direct visualisation, clinical correlation or ENT opinion. Only 24.3\% (25/102) of patients were referred and seen by ENT, 14.6\% (15/102) of which had an interval PET scan and 8.7\% (9/102) proceeded to tissue diagnosis. There was one oropharyngeal cancer identified and one unexpected metastasis from esophageal cancer.

Conclusion Incidental uptake on PET/CT in the oropharynx is common. However, malignancy is rare (1.9\%) and, when present, is associated with high SUVmax and asymmetrical uptake. Imaging results must be correlated clinically. These patients should be seen by an ENT specialist yet most may not require further investigations.
\end{abstract}

Keywords Head and neck $\cdot$ Positron emission tomography $\cdot$ Oropharynx $\cdot$ Head and neck cancer

\section{Introduction}

Head and neck malignancy represents $3 \%$ of all newly diagnosed cancers in the UK, with approximately 11945 cases diagnosed every year [1]. The most common histologic type is squamous cell carcinoma (SCC). Despite substantial advancements in surgical techniques and pharmacological therapies over the past decades, the prognosis of most head

Iulia Bujoreanu

ibujoreanu01@gmail.com

1 Head and Neck Unit, Imperial College Healthcare NHS

Trust, Fulham Palace Road, London W6 8RF, UK

2 Imperial College London, South Kensington, London SW7 2BU, UK

3 Department of Nuclear Medicine and Radiology, Imperial College Healthcare NHS Trust, Fulham Palace Road, London W6 8RF, UK and neck cancers remains poor. This is partly because of advanced disease at the time of presentation in over $60 \%$ of patients. Moreover, synchronous and metachronous malignancies are common due to the phenomenon of 'field cancerisation' in the upper aerodigestive tract and the effect of tobacco smoking and alcohol consumption [2-4]. These findings are supported by a recent meta-analysis showing that patients with hypopharyngeal and oropharyngeal malignancies are at the highest risk of concurrent malignancies [5].

Positron emission tomography (PET) with fluorodeoxyglucose (FDG) utilises whole-body imaging to visualise the uptake of glucose and subsequent glycolysis within cells. PET imaging demonstrates metabolically active tissues and detects metabolic abnormalities prior to morphological changes [6]. Combined with structural imaging modalities such as computed tomography (CT) or magnetic resonance imaging (MRI), it provides functional and anatomical 
information. Standardised uptake values (SUV) have been developed to semi-quantitatively measure FDG uptake related to surrounding tissues, which considers the measured activity in a region of interest (ROI), the amount of tracer injected and patient weight.

Within the head and neck there are several areas that have physiologic increased uptake which can make interpretation of these images challenging. Furthermore, physiologic uptake can be asymmetric. Common sites include the lymphoid tissue within the Waldeyer's ring, the extraocular muscles, the muscles of mastication and the three major salivary glands. High uptake in the vocal cords and the tongue can be associated with phonation at the time of FDG administration. Uptake in the lymphoid oropharyngeal tissue is typically increased in children and young adults. These areas of physiologic FDG uptake in the head and neck have been often documented in patients with various malignancies, such as lung cancer and haematological malignancies [7-9]. Additionally, previous chemotherapy, radiation therapy and surgery, or any other cause of active inflammation can also cause increased FDG uptake, which can appear asymmetrical [10]. The aim of this article is to investigate the significance of incidental FDG uptake in the Waldeyer's ring and to assess its value in predicting occult oropharyngeal malignancy.

\section{Materials and methods}

\section{Patients}

All FDG-PET/CT scans performed and reported at Imperial College NHS Trust, UK between 1st January 2012 and 1st December 2018 were scanned for the keywords "tonsil", "tongue" and "lingual". The selected reports were then fully read to ascertain whether there was any uptake in the region of interest (tonsils or base of the tongue) and to collect clinical and radiological data. Collected data included gender, indication for PET scan, topography of uptake, asymmetry, $\mathrm{SUV}_{\max }$ in the region of interest and recommendations in the official radiology report. The medical records were subsequently analysed for potential appointments with the otolaryngology service, further investigations and tissue biopsies. Data for the study were collected between the 1st November 2018 and 30th November 2019. Incidental uptake rates on FDG/PET/CT scans were calculated from January 2015 onwards as data for total numbers of scans performed in our unit was not available prior to this date. The study did not require ethics committee approval.

\section{Inclusion and exclusion criteria}

Included patients were older than 18 years and had unexpected or incidental FDG uptake in the oropharynx during a PET/CT scan. This was either during a whole body imaging study or during a dedicated head and neck scan. Patients with physiological uptake were included. Exclusion criteria included age less than 18 years, a current or previous diagnosis of head and neck malignancy apart from thyroid cancer or haematological malignancy and lack of FDG uptake in the region of interest. Patients were also excluded if their medical records were not available for review, if they passed away before having the opportunity to investigate the incidental FDG uptake or if they did not turn up for further investigations.

\section{Imaging protocol and image analysis}

Cross-sectional imaging was acquired using a Siemens Biograph $^{\mathrm{TM}}$ TruePoint TrueV PET scanner (Munich, Germany) with true $\mathrm{X}$ reconstruction. Patient were asked to fast for a minimum of $6 \mathrm{~h}$ prior to their radiology appointment and capillary blood glucose levels were measured using a point-ofcare device prior to the administration of radioisotope. FDG was administered via a peripheral intravenous line. The images were then reviewed and reported by a nuclear medicine consultant radiologist.

\section{Follow-up}

Patients were followed-up for development of any late head and neck malignancy for a minimum time of 12 months, starting from the time of their first FDG-PET/CT with incidental oropharyngeal uptake.

\section{Clinical outcomes}

The main measured clinical outcome was whether any of the patients with incidental oropharyngeal uptake had a concurrent head and neck malignancy. The secondary outcome looked at whether any of the included patients developed a head and neck malignancy during the follow-up period. Data were presented as descriptive statistics, using mean and standard deviation for normally distributed data, and median and range for not normally distributed data. Ratios were presented as percentages.

\section{Results}

Incidental uptake rates varied between 0.64 and $1.42 \%$ of all PET CT scans per year with an average of $0.88 \%$ (Table 1). In a period of 82 months, a total of 724 patients 
Table 1 Results—rates of incidental uptake

\begin{tabular}{lll}
\hline Year & $\begin{array}{l}\text { Total FDG-PET/CT } \\
\text { scans performed }\end{array}$ & $\begin{array}{l}\text { FDG-PET/CT scans with } \\
\text { incidental oropharyngeal uptake } \\
(\%)\end{array}$ \\
\hline $2015-2016$ & 2639 & $17(0.64 \%)$ \\
$2016-2017$ & 2799 & $22(0.79 \%)$ \\
$2017-2018$ & 3015 & $20(0.66 \%)$ \\
$2018-2019$ & 1899 & $27(1.42 \%)$ \\
\hline
\end{tabular}

showed head and neck FDG uptake. From these, 434 patients were excluded for having a suspected or previous diagnosis of head and neck malignancy excluding thyroid cancer. A further 135 patients were excluded for having or being suspected of having a haematological malignancy, 45 patients were excluded as they did not have any FDG uptake in the lingual or palatine tonsils and seven patients were excluded as there was full clinical notes were not available. One patient was not included in the study as he declined further investigations and was lost to followup. Finally, 102 patients were included in the analysis (Table 2).

We found a slight preponderance towards female gender (56.9\%) with no clinical significance. Age ranged between 18 and 90 years with a median of 55.5. Of the included patients, $16 \%$ were current tobacco smokers, while $28 \%$ were former smokers. Clinical indication for the scan was as part of staging for other malignancies in 58.8\% $(n=60)$, performed for patients with auto-immune diseases such as vasculitis or granulomatous diseases in $19.4 \%(n=20)$, suspicion of new diagnosis of cancer in 9.8\% $(n=10)$, as investigation for tuberculosis in $5.8 \%(n=6)$ and to look occult infection in $5.8 \%(n=6)$ of patients. Of the patients who underwent PET/CT for staging of underlying malignancies, $30 \%(n=18)$ had lung, $13.3 \%(n=8)$ had colorectal, $13.3 \%$ $(n=8)$ had breast, $10 \%(n=6)$ had melanoma, $8.3 \%(n=5)$ had multiple myeloma, $6.7 \%(n=4)$ had esophageal, $3.3 \%$ $(n=2)$ had uterine and $3.3 \%(n=2)$ had cervical cancer. The remaining $11.8 \%(n=7)$ of malignancies were cancers of unknown primary, pituitary, brain, thyroid, gastric and ovarian.

Capillary blood glucose levels ranged between 3.1 and $9 \mathrm{mmol} / \mathrm{l}$ with an average of $5.5 \mathrm{mmol} / \mathrm{l}$. Patients received on average $363.6 \mathrm{MBq}$ of FDG, and image acquisition time averaged 63 min post-injection.

Oropharyngeal uptake was asymmetrical in 57.8\% $(n=59)$. Incidental uptake was more common in the tonsils $(55.9 \% ; n=57)$ than in the base of the tongue $(31.4 \%$; $n=32)$, with $12.7 \%(n=13)$ of patients demonstrating uptake at both sites (Table 3). $\mathrm{SUV}_{\text {max }}$ measurements were reported in $51 \%$ of scans $(n=51)$ and varied between 3.1 and 25.3 (mean 9.1).
Table 2 Results-demographics and basic clinical characteristics and radiographic findings

\begin{tabular}{|c|c|c|}
\hline \multicolumn{3}{|l|}{ Demographics } \\
\hline$N$ & 102 & \\
\hline \multicolumn{3}{|l|}{ Gender } \\
\hline Female & 58 & $56.9 \%$ \\
\hline Male & 44 & $43.1 \%$ \\
\hline \multicolumn{3}{|l|}{ Age } \\
\hline Mean & 54.2 & $18-90$ \\
\hline \multicolumn{3}{|l|}{ Tobacco exposure } \\
\hline Current smoker & 16 & $15.7 \%$ \\
\hline Ex-smoker & 29 & $28.4 \%$ \\
\hline Never smoker & 57 & $55.9 \%$ \\
\hline \multicolumn{3}{|l|}{ Clinical indication } \\
\hline Staging for known malignancy & 60 & $58.8 \%$ \\
\hline Lung & 18 & $30 \%$ \\
\hline Colorectal & 8 & $13.3 \%$ \\
\hline Breast & 8 & $13.3 \%$ \\
\hline Skin & 6 & $10 \%$ \\
\hline Multiple myeloma & 5 & $8.3 \%$ \\
\hline Esophageal & 4 & $6.7 \%$ \\
\hline Uterine & 2 & $3.3 \%$ \\
\hline Cervical & 2 & $3.3 \%$ \\
\hline Cancer of unknown origin & 2 & $3.3 \%$ \\
\hline Pituitary & 1 & $1.7 \%$ \\
\hline Brain & 1 & \\
\hline Thyroid & 1 & \\
\hline Gastric & 1 & \\
\hline Ovarian & 1 & \\
\hline Investigating potential cancer & 10 & $9.8 \%$ \\
\hline Investigating vasculitis & 20 & $19.6 \%$ \\
\hline Investigating tuberculosis & 6 & $5.8 \%$ \\
\hline Investigating occult infections & 6 & $5.8 \%$ \\
\hline
\end{tabular}

Official radiology reports described $41.2 \%(n=42)$ of findings as likely physiological; however $52.9 \%(n=54)$ of reports advised further action. The most frequent recommendation was direct visualisation in $41.2 \%(n=42)$, correlation with clinical findings in $13.7 \%(n=14)$ and specialty otolaryngology opinion in $3.9 \%(n=4)$ of reports. Of these patients, only $24.5 \%(n=25)$ were referred and reviewed by an otolaryngologist. Patients reviewed by an ENT specialist were more likely to have asymmetrical uptake (84\%) and SUVmax values were on median 7.65 (range 3.1-20.1). Of these, nine patients were reassured and discharged following their first appointment with ENT, eight patients had subsequent follow-up and 15 required an interval PET/CT. The interval scans showed partial or complete resolution in all cases. Furthermore, nine patients proceeded to tissue diagnosis. In the subgroup of patients which underwent biopsy, three had tonsil uptake, 
Table 3 Results-radiographic findings, follow-up and further investigations $(N=102)$

\begin{tabular}{lll}
\hline Results & & \\
\hline PET uptake & & \\
Asymmetry & 59 & $57.8 \%$ \\
Base of tongue & 32 & $31.4 \%$ \\
Palatine tonsils & 57 & $55.9 \%$ \\
SUX & Median 7.65 (range & \\
& $3.1-25.3)$ & \\
Report recommendations & & $41.2 \%$ \\
Direct visualisation & 42 & $13.7 \%$ \\
Clinical correlation & 14 & $3.9 \%$ \\
Specialist opinion & 4 & \\
Outcomes & & $24.5 \%$ \\
Seen in ENT clinic & 25 & $36 \%$ \\
Reassured and discharged & 9 & $32 \%$ \\
Further follow-up arranged & 8 & \\
Further investigations & & $14.7 \%$ \\
Repeat imaging & 15 & $8.8 \%$ \\
Tissue diagnosis & 9 & $1 \%$ \\
Declined further follow-up & 1 & \\
\hline
\end{tabular}

four had base of tongue uptake and two had uptake in both regions, uptake was asymmetrical in $66.7,44 \%$ had history of past or current smoking and $\mathrm{SUV}_{\max }$ values were on median 7.6 (range 3.1-15.3). Biopsies revealed follicular hyperplasia (3), low-grade dysplasia (1), amyloid tissue (1), tongue base cysts (1), reactive lymph node (1), normal lymphoid tissue (1) and metastatic adenocarcinoma (1).

The biopsy positive for metastatic adenocarcinoma belonged to a 73 year-old man with a history of Ivor Lewis esophagectomy 5 years previously, who presented with a new neck lump. The PET/CT showed a soft tissue tumour (SUVmax 4.0) at the right thoracic inlet with extension into the right lobe of the thyroid and trachea, and "faint" activity $\left(\mathrm{SUV}_{\max } 3.1\right)$ in the base of tongue extending to the valeculla, with some soft tissue asymmetry on the non-contrast CT component. Direct visualisation was recommended.

A second patient with a radiologically diagnosed base of tongue tumour was a 66 year-old man with an advanced T4N1 rectal cancer with liver and lung metastases. The $\mathrm{PET} / \mathrm{CT}$ revealed a left valecullar and tongue base lesion with increased FDG uptake crossing the midline, suggestive of a second primary. Following discussion at the multidisciplinary team meeting, it was decided not to further investigate the new primary in view of the patient's poor prognosis.

None of the other patients developed oropharyngeal malignancy at a later date. The median follow-up was 28.6 months with a minimum follow-up of 12 months.

\section{Discussion}

Incidental FDG uptake in the head and neck during PET scans is common. However, to the best of our knowledge, no studies have investigated incidental FDG uptake in the oropharynx specifically. Incidental PET uptake in the head and neck was analysed in 16 papers and was shown to occur in $13.8 \%$ of scans on average (Table 4) [11-25]. The presence of PET incidentalomas was associated with a significant increase in time to commencement of treatment [14]. Incidental uptake was typically benign, in the form of inflammatory or reactive lymphoid hyperplasia [13-16, 20, 26]. Unexpected foci of uptake on the PET/CT represented malignant deposits from the primary cancer with rates varying between 3 and 50\% (average 27\%), with rates higher in patients with parotid uptake [24]. Of note, it was shown that $\mathrm{SUV}_{\text {max }}$ from cervical lymph nodes in patients with malignant incidental lesions was on average higher than in patients with benign findings [23].

New, truly positive scans were uncommon. A new malignancy was diagnosed in $0.5-10 \%$ of patients with incidental head and neck uptake, more commonly in smokers [17]. Moreover, synchronous cancers were shown to be at a more incipient stage when diagnosed (stages I and II) $[17,19,21]$. Synchronous primaries in the Waldeyer's ring were rare. There was one case of a tongue base SCC diagnosed following staging investigations with ${ }^{68} \mathrm{Ga}$ prostate specific membrane antigen (PSMA) PET/CT for a prostate cancer [18]. In the series by Cho et al. looking at uptake in the piriform sinus, there was one case of metastatic deposit from an incidental tonsil SCC [23]. Patel et al. diagnosed a further tongue SCC in a patient undergoing FDG PET/ CT for a known lung primary, who had frank clinical evidence of a synchronous head and neck malignancy [14]. There was one case of a patient diagnosed with tonsil SCC following evidence of increased but symmetrical uptake $\left(\mathrm{SUV}_{\max }\right.$ 3.2) during FDG PET/CT, suggesting that pattern of uptake might not be a useful predictor of potential malignancy [16].

In our unit, the presence of incidental oropharyngeal PET uptake was $0.88 \%$, which is lower compared to the rate of incidental total head and neck uptake of $13.8 \%$. This is indeed a surprizing finding, more so as the incidence of oropharyngeal malignancy is increasing. This perhaps suggests increasing expertise with PET imaging leading to a reduced number of reporting of incidental lesions which reveals the subjectivity in interpreting these scans. This might be a reflection of recent improvements in PET/CT scanners with innovations in detection technology and spatial resolution [27]. There has been a drastic change from analogue to digital equipment which can be seen in the adoption of digital detectors. These have been 
Table 4 Literature review and study characteristics

\begin{tabular}{|c|c|c|c|c|c|c|c|}
\hline First author, year & $n$ & Age (years) & $\begin{array}{l}\text { Study type, level } \\
\text { of evidence }\end{array}$ & $\begin{array}{l}\text { Cohort (underly- } \\
\text { ing pathology) }\end{array}$ & $\begin{array}{l}\mathrm{H} \& \mathrm{~N} \text { incidental } \\
\text { findings }\end{array}$ & $\mathrm{H} \& \mathrm{~N}$ malignancy & $\begin{array}{l}\text { H\&N malignancy } \\
\text { described }\end{array}$ \\
\hline Britt $^{\mathrm{a}} 2018$ [11] & 293 & 62.8 & $\begin{array}{l}\text { Retrospective } \\
\text { level III }\end{array}$ & H\&N cancer & $45 \%$ & $N=1$ & $\begin{array}{l}1 \text { parotid malig- } \\
\text { nancy }\end{array}$ \\
\hline $\begin{array}{l}\text { Casselden }^{\text {a }} 2019 \\
\text { [12] }\end{array}$ & 93 & $34-85$ & $\begin{array}{l}\text { Retrospective } \\
\text { level III }\end{array}$ & H\&N cancer & $2.1 \%$ & None & None \\
\hline Osman $^{\mathrm{a}} 2017$ [13] & 764 & $68-82$ & $\begin{array}{l}\text { Retrospective } \\
\text { level III }\end{array}$ & Prostate cancer & $0.2 \%$ & $N=1$ & $\begin{array}{l}1 \text { base of tongue } \\
\text { SCC }\end{array}$ \\
\hline $\mathrm{Ali}^{\mathrm{a}} 2017$ [14] & 273 & $38-81$ & $\begin{array}{l}\text { Prospective level } \\
\text { III }\end{array}$ & $\begin{array}{l}\text { Lung, oesopha- } \\
\text { geal, H\&N, lym- } \\
\text { phoma, genitou- } \\
\text { rinary, gastric, } \\
\text { melanoma, other } \\
\text { cancer }\end{array}$ & NR & $N=3$ & $\begin{array}{l}1 \text { parotid adeno- } \\
\text { carcinoma, } 1 \\
\text { laryngeal SCC and } \\
1 \text { hypopharyngeal } \\
\text { SCC }\end{array}$ \\
\hline $\begin{array}{l}\text { Schaarschmid } \\
2017 \text { [15] }\end{array}$ & 81 & $54.4 \pm 15$ & $\begin{array}{l}\text { Retrospective } \\
\text { level III }\end{array}$ & H\&N cancer & $32 \%$ & None & None \\
\hline Conrad $^{\mathrm{a}} 2016$ [16] & 181 & $26-87$ & $\begin{array}{l}\text { Retrospective } \\
\text { level III }\end{array}$ & Melanoma & $1.1 \%$ & None & None \\
\hline Lee, 2016 [17] & 317 & 63 & $\begin{array}{l}\text { Retrospective } \\
\text { level III }\end{array}$ & Esophageal cancer & $\begin{array}{l}\text { NR (nasopharynx } \\
\text { only) }\end{array}$ & $N=4$ & $\begin{array}{l}3 \text { hypopharyngeal } \\
\text { SCC and } 1 \text { oro- } \\
\text { pharyngeal SCC }\end{array}$ \\
\hline $\mathrm{Cho}^{\mathrm{a}}, 2016[18]$ & 56,585 & $58.2 \pm 11.4$ & $\begin{array}{l}\text { Retrospective } \\
\text { level III }\end{array}$ & $\begin{array}{l}\text { Known cancer } \\
\text { (without } \mathrm{H} \& \mathrm{~N} \text { ) }\end{array}$ & $\begin{array}{l}0.7 \% \text { (piriform } \\
\text { sinus only) }\end{array}$ & $N=29$ & $\begin{array}{l}1 \text { metastatic deposit } \\
\text { from incidental } \\
\text { tonsil SCC }\end{array}$ \\
\hline Seo, 2015 [19] & 1342 & $34-78$ & $\begin{array}{l}\text { Retrospective } \\
\text { level III }\end{array}$ & Prostate cancer & $\begin{array}{l}2.1 \% \text { (parotid } \\
\text { only) }\end{array}$ & $N=8$ & $\begin{array}{l}8 \text { metastatic depos- } \\
\text { its from primary } \\
\text { malignancy }\end{array}$ \\
\hline $\begin{array}{l}\text { Williams } 2015 \\
\text { [20] }\end{array}$ & 609 & NR & $\begin{array}{l}\text { Retrospective } \\
\text { level III }\end{array}$ & Lung cancer & $12.5 \%$ & $N=1$ & $\begin{array}{l}1 \text { papillary cancer } \\
\text { thyroid }\end{array}$ \\
\hline Gobel 2014 [21] & 592 & $22-85$ & $\begin{array}{l}\text { Retrospective } \\
\text { level III }\end{array}$ & Lung cancer & $11 \%$ & $N=4$ & $\begin{array}{l}2 \text { laryngeal SCC, } \\
1 \text { oral cavity } \\
\text { SCC; } 1 \text { parotid } \\
\text { undifferentiated } \\
\text { carcinoma and } 1 \\
\text { osteosarcoma of } \\
\text { the mandible }\end{array}$ \\
\hline Patel $^{\text {a }} 2014$ [22] & 1846 & 70 & $\begin{array}{l}\text { Retrospective } \\
\text { level III }\end{array}$ & Lung cancer & $2.6 \%$ & $N=3$ & 1 tongue $\mathrm{SCC}$ \\
\hline $\begin{array}{l}\text { Al-Hakami } 2011 \\
\text { [23] }\end{array}$ & 1565 & NR & $\begin{array}{l}\text { Retrospective } \\
\text { level III }\end{array}$ & Non-H\&N cancer & $2.4 \%$ & $N=8$ & $\begin{array}{l}5 \text { thyroid cancer, } 2 \\
\text { parotid cancer and } \\
1 \text { cervical node } \\
\text { positive for SCC }\end{array}$ \\
\hline Heusner 2009 [24] & 590 & $55.4 \pm 13.3$ & $\begin{array}{l}\text { Retrospective } \\
\text { level III }\end{array}$ & Non-H\&N cancer & $60 \%$ & $N=2$ & $\begin{array}{l}1 \text { palatine tonsil } \\
\text { SCC and } 1 \text { oral } \\
\text { floor SCC }\end{array}$ \\
\hline Choi 2005 [25] & 547 & $60.5 \pm 10.5$ & $\begin{array}{l}\text { Retrospective } \\
\text { level III }\end{array}$ & $\begin{array}{l}\text { New cancer diag- } \\
\text { nosis }\end{array}$ & NR & $N=7$ & NR \\
\hline
\end{tabular}

${ }^{a}$ Excluded thyroid uptake, $H \& N$ head and neck, $n$ number of patients included in study, $N R$ not reported

shown to reduce noise and improve lesion detectability and diagnostic confidence and may reduce the number of false positives [28].

The rate of incidental oropharyngeal PET uptake which harboured malignancy in this study was $1.9 \%$ which is slightly lower than the rates found in the head and neck literature review. This is certainly much lower than the rates documented in the thyroid [29], parotid [24] and piriform sinus [23]. This high false positive rate can be party explained by the intrinsic nature of immune tissue which can be often found in a reactive phase. These findings are somewhat reassuring, suggesting that the majority of incidental PET uptake is benign and only a very small number of patients will present with true malignancy. Furthermore, 
the rate of positive malignancy in patients undergoing tissue biopsy was low at $11 \%$ suggestive that the rate of false positives on PET/CT is still high. Therefore, there might be a case for acquiring magnetic resonance imaging to further characterise these lesions prior to tissue diagnosis. Nevertheless, as oropharyngeal malignancy becomes more common, one cannot be too careful in further investigation of these patients.

Whereas guidelines exist for managing incidental FDG uptake in the parotid, nasopharynx, esophagus, pancreas, uterus and ovaries, no consensus yet exists for managing oropharyngeal uptake [30]. With regards to uptake in the palatine tonsils, this was shown to be on mean $\mathrm{SUV}_{\max }$ higher in SCC $(9.36+$ or -4.54$)$ than in contralateral healthy tonsils $(2.54+$ or $-0.88 ; p<0.0001)$ or in control subjects $(2.98+$ or $-1.08 ; p<0.0001)$ [31]. A further study proposes that a difference of above $\mathrm{SUV}_{\max } 1.6$ between the two tonsils suggests a site of biopsy in SCC of unknown primary [32]. These guidelines, however, are limited by small numbers and the poor validity of $\mathrm{SUV}_{\max }$ values across different centres and therefore results lose comparability. Despite this, the current findings suggest that the risk of malignancy is small and clinicians can find reassurance. In addition, many of the patients undergoing PET imaging will undergo subsequent follow-up as part of their original pathology which presents an opportunity for monitoring of changes.

The cost implications involved in further investigating these radiological findings also needs discussed. Adams et al. calculated costs of follow-up in 215 consecutive patients undergoing PET-CT in Ontario, Canada [33]. Of these, 161 (74.9\%) had incidental findings and 75 reports had recommendations for further follow-up. The cost for the recommended investigations was calculated at $\$ 127.56$ (US Dollars) per each patient undergoing PET-CT. However, this did not take into account any costs associated with new referrals and appointments. The cost of new appointments in the Ears, Nose and Throat department in Imperial College Healthcare NHS Trust, UK average at $£ 120$ (GBP) excluding endoscopic examination, suggesting that costs might be as high as $£ 220$ for patients requiring follow-up of incidental lesions within our unit.

\section{Limitations}

This is the first study investigating incidental PET/CT uptake in the oropharynx and we acknowledge certain limitations. Despite the considerable time-frame, the number of included patients remains small. Organising large multi-centre trials, however, remains difficult in view of the heterogeneity of PET scanners and high variability in local radiology expertise. Furthermore, SUV values vary depending on image quality (noise, resolution), tumour size (with smaller tumours demonstrating lower SUV), as well as on the acquisition and processing of images. As SUV vary among different institutions and studies, results are often non-comparable [34, 35].

Due to the wide time-frame of the present study, there was also variation in the available PET technology, scan report and recommendation and examination, investigation and follow-up of included patients.

\section{Conclusion}

Oropharyngeal SCC is becoming increasingly common and early diagnosis is of paramount importance [36]. However, the current study suggests that, whereas incidental FDG uptake in the Waldeyer's ring is common on PET imaging, it is unlikely to harbour any malignancy. When oropharyngeal malignancy occurs, it is typically associated with clinical signs and structural changes on the CT component. This emphasises the importance of direct visualisation when investigating incidental oropharyngeal PET uptake. The development of a risk-stratification model for patients with unexplained oropharyngeal uptake who require a second opinion needs to be addressed. High risk factors include tobacco consumption and alcohol intake, upper gastrointestinal tract malignancies [37] and lung malignancies [38, 39]. Despite its variability, $\mathrm{SUV}_{\max }$ has been shown to be high in cases of true malignancy in the palatine and lingual tonsils and, thus, should be taken into consideration when assessing risk. Furthermore, radiology reports often comment on suspicious uptake despite apparent symmetry and give recommendations on further follow-up or repeat imaging. This can be an invaluable tool in stratifying high-risk patients and reducing unnecessary investigations. Lastly, with the advent of liquid biopsies in diagnosing malignancy and detection of HPV infection, clinicians can further predict head and neck malignancy risk [40]. However, developing a feasible and accurate risk-stratification model for patients with incidental uptake in the oropharynx requires additional work.

Funding There was no funding required for this study.

Availability of data and materials Anonymised data available upon request.

\section{Declarations}

Conflict of interest The authors have no conflicts of interest to declare.

Ethics approval Not required. Approval granted from local department.

Consent for publication All authors have consented to publication in European Archives of Oto-Rhino-Laryngology. 
Open Access This article is licensed under a Creative Commons Attribution 4.0 International License, which permits use, sharing, adaptation, distribution and reproduction in any medium or format, as long as you give appropriate credit to the original author(s) and the source, provide a link to the Creative Commons licence, and indicate if changes were made. The images or other third party material in this article are included in the article's Creative Commons licence, unless indicated otherwise in a credit line to the material. If material is not included in the article's Creative Commons licence and your intended use is not permitted by statutory regulation or exceeds the permitted use, you will need to obtain permission directly from the copyright holder. To view a copy of this licence, visit http://creativecommons.org/licenses/by/4.0/.

\section{References}

1. Head and neck cancers incidence statistics | Cancer Research UK. Cancer Research UK, https://www.cancerresearchuk.org/ health-professional/cancer-statistics/statistics-by-cancer-type/ head-and-neck-cancers/incidence\#theading-Four 2016, Accessed on 24 March 2019

2. Hashibe M, Brennan P, Chuang S, Boccia et al (2009) Interaction between tobacco and alcohol use and the risk of head and neck cancer pooled analysis in the international head and neck cancer epidemiology consortium. Cancer Epidemiol Biomarkers Prev 18:541-550

3. Waridel F, Estreicher A, Bron L et al (1997) Field cancerisation and polyclonal p53 mutation in the upper aero- digestive tract. Oncogene 14:163-169

4. Morris LGT, Sikora AG, Hayes RB et al (2011) Anatomic sites at elevated risk of second primary cancer after an index head and neck cancer. Cancer Causes Control 22:671-679

5. Bugter O, van de Ven SEM, Hardillo JA et al (2019) Early detection of esophageal second primary tumors using Lugol chromoendoscopy in patients with head and neck cancer: a systematic review and meta-analysis. Head Neck 41:1122

6. Dirix P, Vandecaveye V, De Keyzer F et al (2009) Dose painting in radiotherapy for head and neck squamous cell carcinoma: value of repeated functional imaging with (18)F-FDG PET, (18) F-fluoromisonidazole PET, diffusion-weighted MRI, and dynamic contrast-enhanced MRI. J Nucl Med 50:1020-1027

7. Nakamura S, Okochi K, Murata Y et al (2009) [18F]Fluorodeoxyglucose-PET/CT differentiation between physiological and pathological accumulations in head and neck. Nucl Med Commun 30:498-503

8. Purohit BS, Ailianou A, Dulguerov N et al (2014) FDG-PET/CT pitfalls in oncological head and neck imaging. Insights Imaging 5:585-602

9. Liu Y, Ghesani NV, Zuckier LS (2010) Physiology and pathophysiology of incidental findings detected on FDG-PET scintigraphy. Semin Nucl Med 40:294-315

10. Nakamoto Y, Tatsumi M, Hammoud D et al (2005) Normal FDG distribution patterns in the head and neck: PET/CT evaluation. Radiology 234:879-885

11. Britt CJ, Maas AM, Kennedy TA et al (2018) Incidental findings on FDG PET/CT in head and neck cancer. Otolaryngol Neck Surg 158:484-488

12. Casselden E, Sheerin F, Winter SC (2019) Incidental findings on 18 FDG PET CT in head and neck cancer. A retrospective case control study of incidental findings on 18 FDG PET CT in patients with head and neck cancer. Eur Arch Oto Rhino Laryngol 276:243-247

13. Gobel Y, Valette G, Abgral R et al (2014) Interpretation of suspect head and neck fixations seen on PET/CT in lung cancer. Eur Ann Otorhinolaryngol Head Neck Dis 131:217-221
14. Patel A, Perry T, Hunt I et al (2014) Should we routinely investigate incidental head and neck findings on 18-fluorodeoxyglucose positron emission tomography in patients being staged for nonsmall cell lung cancer? A Retro Anal Thorac Cardiovasc Surg 63:604-608

15. Al-Hakami HA, Makis W, Anand S et al (2011) Head and neck incidentalomas on positron emission tomographic scanning: ignore or investigate? J Otolaryngol Head Neck Surg 40:384-390

16. Heusner TA, Hahn S, Hamami ME et al (2009) Incidental head and neck 18F-FDG uptake on PET/CT without corresponding morphological lesion: early predictor of cancer development? Eur J Nucl Med Mol Imaging 36:1397-1406

17. Choi JY, Lee KS, Kwon OJ et al (2005) Improved detection of second primary cancer using integrated $[18 \mathrm{~F}]$ fluorodeoxyglucose positron emission tomography and computed tomography for initial tumor staging. J Clin Oncol 23:7654-7659

18. Osman MM, Iravani A, Hicks RJ et al (2017) Detection of synchronous primary malignancies with $68 \mathrm{Ga}$-labeled prostate-specific membrane antigen PET/CT in patients with prostate cancer: frequency in 764 patients. J Nucl Med 58:1938-1942

19. Ali SA, Hamed MAE (2017) The diagnostic efficacy of whole body 18 F-FDG PET CT in detection of unexpected second primary malignancy in cancer patients. Egypt J Radiol Nucl Med 48:671-676

20. Schaarschmidt BM, Gomez B, Buchbender C et al (2017) Is integrated 18F-FDG PET/MRI superior to $18 \mathrm{~F}-\mathrm{FDG}$ PET/CT in the differentiation of incidental tracer uptake in the head and neck area? Diagn Interv Radiol 23:127-132

21. Conrad F, Winkens T, Kaatz M et al (2016) Retrospective chart analysis of incidental findings detected by (18) F-fluorodeoxyglucose-PET/CT in patients with cutaneous malignant melanoma. J Dtsch Dermatol Ges 14:807-816

22. Lee JS, Ahn JY, Choi KD, et al. Synchronous second primary cancers in patients with squamous esophageal cancer: clinical features and survival outcome. Korean J Intern Med; 31, http://www.ncbi. nlm.nih.gov/pubmed/26864297 2016, Accessed on 9 December 2018

23. Cho YS, Moon SH, Choi JY et al (2016) Clinical significance of incidental 18F-FDG uptake in the pyriform sinus detected by PET/CT. Clin Nucl Med 41:e82-e86

24. Seo YL, Yoon DY, Baek S et al (2015) Incidental focal FDG uptake in the parotid glands on PET/CT in patients with head and neck malignancy. Eur Radiol 25:171-177

25. Williams SP, Kinshuck AJ, Williams C et al (2015) Incidental head and neck findings on 18F-fluoro-deoxy-glucose positron emission tomography computed tomography. J Laryngol Otol 129:898-902

26. Williams SP, Kinshuck AJ, Williams C et al (2015) Incidental head and neck findings on ${ }^{18} \mathrm{~F}$-fluoro-deoxy-glucose positron emission tomography computed tomography. J Laryngol Otol 129:898-902

27. Vandenberghe S, Moskal P, Karp JS (2020) 2020 State of the art in total body PET. EJNMMI Phys 71(7):1-33

28. Schillaci O, Urbano N (2019) Digital PET/CT: a new intriguing chance for clinical nuclear medicine and personalized molecular imaging. Eur J Nucl Med Mol Imaging 46:1222-1225

29. Agrawal K, Weaver J, Ul-Hassan F et al (2015) Incidence and significance of incidental focal thyroid uptake on ${ }^{18} \mathrm{~F}$-FDG PET study in a large patient cohort: retrospective single-centre experience in the United Kingdom. Eur Thyroid J 4:115-122

30. Pencharz D, Nathan M, Wagner TL (2017) Evidence based management of incidental focal uptake of fluorodeoxyglucose on PETCT. Br J Radiol 91:20170774

31. Davison JM, Ozonoff A, Imsande HM et al (2010) Squamous cell carcinoma of the palatine tonsils: FDG standardized uptake 
value ratio as a biomarker to differentiate tonsillar carcinoma from physiologic uptake. Radiology 255:578-585

32. Pencharz D, Dunn J, Connor S et al (2019) Palatine tonsil SUVmax on FDG PET-CT as a discriminator between benign and malignant tonsils in patients with and without head and neck squamous cell carcinoma of unknown primary. Clin Radiol 74(165):e17-165.e23

33. Adams SJ, Rakheja R, Bryce R et al (2018) Incidence and economic impact of incidental findings on 18F-FDG PET/CT imaging. Can Assoc Radiol J 69:63-70

34. Kinahan PE, Fletcher JW (2010) Positron emission tomographycomputed tomography standardized uptake values in clinical practice and assessing response to therapy. Semin Ultrasound CT MR 31:496-505

35. Boellaard R, Krak NC, Hoekstra OS et al (2004) Effects of noise, image resolution, and ROI definition on the accuracy of standard uptake values: a simulation study. J Nucl Med 45:1519-1527

36. Anderson CM, Chang T, Graham MM et al (2015) Change of maximum standardized uptake value slope in dynamic triphasic [18F]-fluorodeoxyglucose positron emission tomography/computed tomography distinguishes malignancy from postradiation inflammation in head-and-neck squamous cell carcinoma: a prospective trial. Int J Radiat Oncol 91:472-479
37. Muto M, Hironaka S, Nakane M et al (2002) Association of multiple Lugol-voiding lesions with synchronous and metachronous esophageal squamous cell carcinoma in patients with head and neck cancer. Gastrointest Endosc 56:517-521

38. Wax MK, Myers LL, Gabalski EC et al (2002) Positron emission tomography in the evaluation of synchronous lung lesions in patients with untreated head and neck cancer. Arch Otolaryngol Head Neck Surg 128:703-707

39. Schwartz LH, Ozsahin M, Zhang GN et al (1994) Synchronous and metachronous head and neck carcinomas. Cancer 74:1933-1938

40. Qureishi A, Mawby T, Fraser L et al (2017) Current and future techniques for human papilloma virus (HPV) testing in oropharyngeal squamous cell carcinoma. Eur Arch Otorhinolaryngol 274:2675-2683

Publisher's Note Springer Nature remains neutral with regard to jurisdictional claims in published maps and institutional affiliations. 